This item was submitted to Loughborough's Research Repository by the author.

Items in Figshare are protected by copyright, with all rights reserved, unless otherwise indicated.

\title{
Measuring the changing pulse of rivers
}

PLEASE CITE THE PUBLISHED VERSION

https://doi.org/10.1126/science.aao2441

\section{PUBLISHER}

American Association for the Advancement of Science $(\subset)$ The Authors

\section{VERSION}

AM (Accepted Manuscript)

\section{PUBLISHER STATEMENT}

This work is made available according to the conditions of the Creative Commons Attribution-NonCommercialNoDerivatives 4.0 International (CC BY-NC-ND 4.0) licence. Full details of this licence are available at: https://creativecommons.org/licenses/by-nc-nd/4.0/

\section{LICENCE}

CC BY-NC-ND 4.0

\section{REPOSITORY RECORD}

Slater, Louise, and Robert Wilby. 2019. "Measuring the Changing Pulse of Rivers". figshare. https://hdl.handle.net/2134/26203. 


\section{Measuring the changing pulse of rivers}

\section{A 50-year data set shows changes in the seasonal timing of river floods in Europe}

By Louise J . Slater and Robert L. Wilby

Department of Geography, Loughborough University, Loughborough, UK. Email: I.slater@lboro.ac.uk

River flood risks are expected to rise as climate change intensifies the global hydrological cycle and more people live in floodplains (1). Changing risk may be revealed by trends in flood frequency, magnitude, or seasonality, as well as by shifts in the mechanisms that generate inundations (2). However, detection and attribution of climate signals in flood records is often hampered by brief, incomplete, or poor-quality flood data (3). Additionally, it can be difficult to disentangle the effects of changing climate, land cover, channel morphology, and human activities $(2,4)$. On page $\mathrm{n}$ of this issue, Blöschl et al. (5) overcome these problems through a consistent pan-European assessment of observed flood seasonality trends between 1960 and 2010. They thus provide the first evaluation of how climatic changes are influencing flood regimes at the continental scale.

Rather than applying a conventional analysis of flood magnitudes or frequency, the authors use flood seasonality, a more sensitive metric for detecting climate signals in flood regimes (6). They track changes in the timing of the largest annual floods over five decades, using a database that pools flood records from more than 4000 riverine gauging stations across 38 European countries (7). The results show substantial changes in flood timing across Europe. Floods now occur up to several weeks earlier than in the 1960s in areas of Northeastern and Western Europe due to earlier snowmelt and soil moisture maxima, respectively. Possible reasons are higher air temperatures, reduced influence of arctic air masses, and changing time scales of subsurface water storage. In contrast, floods now occur several weeks later in parts of the North Sea and Mediterranean Europe, likely due to changes in the North Atlantic Oscillation and increasing atmospheric flow from the Atlantic in winter, respectively.

Without adaptations, such changes in flood seasonality can profoundly affect agricultural yields, infrastructure safety and operation, hydropower production, water supplies, and water management. The study thus prompts important questions about flood predictability. For example, how have human activities affected the climate variations that contribute to the observed flood seasonality changes? How might changing seasonality manifest in multibasin flood signatures? And how might changes in flood-generating mechanisms affect future patterns of severe flooding (8)?

Over decadal and centennial time scales, variability in hydrologic, ecological, and even geomorphic systems will reflect largescale climate conditions $(9,10)$. However, the interconnectedness of climate and hydrologic regimes is complicated by lag times in fluvial systems and the dynamic behavior of river networks. Following sequences of wet or dry months, years, or decades, groundwater levels fluctuate, increasing or decreasing the spatial extent of river networks and thus the likelihood of flooding (11). Climate may also affect flood seasonality indirectly through changes to wildfire regimes and land cover or by dust loads in snow that decrease snow albedo and alter runoff timing (12).

These natural flood-generating mechanisms do not act in isolation of human land-surface modifications and river regulation. Further research is needed to develop more robust attribution methods (13) that can discern the relative contribution of different flood-generating mechanisms $(2,4)$. This includes going beyond existing trend detection procedures $(4,6)$ and developing more holistic analytical frameworks for linking flood-rich and flood-poor episodes to climate, land cover, river networks, and groundwater conditions.

Whether global river monitoring networks are up to this task is questionable, as hydrometric records and associated metadata are not always quality controlled or publicly accessible. But given that flood risk could rise 20-fold by the end of the 21st century (14), better metrics to describe the vital signs of shifting flood regimes (5) are a step in the right direction.

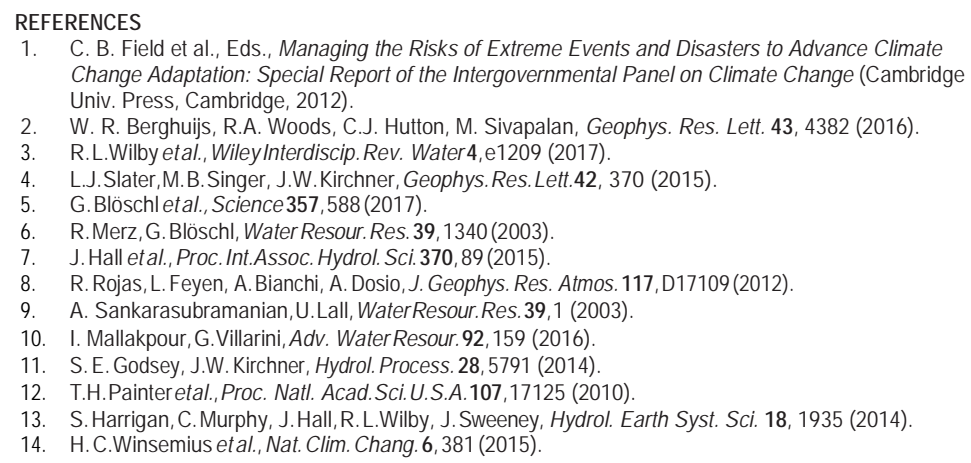

